\title{
The discursive production of professionals about humanizing health: singularity, rights and ethics ${ }^{1}$
}

\author{
Rose Mary Costa Rosa Andrade Silva² \\ Denize Cristina de Oliveira ${ }^{3}$ \\ Eliane Ramos Pereira ${ }^{4}$
}

\begin{abstract}
Objective: to describe the discursive production of professionals about the humanization of health. Method: qualitative study of descriptive approach, inspired by the social representation theory, with 24 professionals in the healthcare field, working in a university hospital with the established humanization policy. The selection of participants was conducted according to criteria of adequacy and diversity for an intentional sample. Data collection was conducted by semistructured interviews. Results: through content analysis, three categories emerged, around which the analyses were conducted: "humanizing health as an act of accepting the other as unique", "humanizing health as a matter of right" and "humanizing health as an ethical issue". The discursive production of professionals is based on a perspective which is based on the humanist prospect with socio-historical bias. Conclusion: healthcare professionals must know the National Humanization Policy in order to provide quality care, promoting the meeting, welcoming and recognition of oneself, others and their profession in the political and socio-historical scenario of their country as a citizen, not only of rights, but also of obligations.
\end{abstract}

Descriptors: Nursing; Ethics; Health; Qualitative Research.

\footnotetext{
${ }^{1}$ Paper extracted from doctoral dissertation "The Symbolic Construction of Health Professionals on Humanization: A Study in the Field of Socia Representations", presented to Instituto de Psicologia Social, Universidade do Estado do Rio de Janeiro, Rio de Janeiro, RJ, Brazil.

2 Doctoral student, Instituto de Psicologia Social, Universidade do Estado do Rio de Janeiro, Rio de Janeiro, RJ, Brazil. Associate Professor, Escola de Enfermagem Aurora Afonso Costa, Universidade Federal Fluminense, Niterói, RJ, Brazil.

3 PhD, Full Professor, Faculdade de Enfermagem, Universidade do Estado do Rio de Janeiro, Rio de Janeiro, RJ, Brazil.

${ }^{4} \mathrm{PhD}$, Associate Professor, Escola de Enfermagem Aurora Afonso Costa, Universidade Federal Fluminense, Niterói, RJ, Brazil.
}

Corresponding Author:

Rose Mary Costa Rosa Andrade Silva Universidade Federal Fluminense

Escola de Enfermagem Aurora de Afonso Costa

Rua Dr. Celestino, 74

Centro

CEP: 24020-091, Niterói, RJ, Brasil

E-mail: roserosauff@gmail.com
Copyright () 2015 Revista Latino-Americana de Enfermagem This is an Open Access article distributed under the terms of the Creative Commons Attribution Non-Commercial License (CC BY-NC).

This license lets others distribute, remix, tweak, and build upon your work non-commercially, and although their new works must also acknowledge you and be non-commercial, they don't have to license their derivative works on the same terms. 


\section{Introduction}

Considering the progress that exists in a highly technological, globalized society, computerized and marked by unprecedented scientific advances, humanizing health seems like a truly anomalous issue. However, the issue occurs in various discussions involving health issues, and especially government guidelines, as an ethical-political intention ${ }^{(1)}$. In addition, nanotechnology is present more and more in various areas of activity in health, in addition to the advances in neuroscience that rely on a logical deductive process, especially in its mathematization, which perfectly meets the three major assumptions of scientific knowledge, namely: universal determinism, naturalism and rationalism(2). Despite all this current technology, the advances that science is able to achieve are confronted with the need for a government policy that incites humanization, the humanized care provided by an individual for an individual.

In fact, the consequence of the relationship with that kind of knowledge, highly technological, is still the issue of one's own dehumanizing, even with the changes that occur every day in various fields of knowledge. Thus, the biopsychosocial, economic and cultural transformations defy people to adopt a systemic vision, and professionals in the "human soul" an aperture to learning something on behalf of others(3). In our society we have boosted the psychosocial phenomenon of globalization and with that, globalized practice arises. The mass media proliferation, and the impact of globalized practices in local scenarios, intensify the conflicts between different forms of knowledge, raising questions about how local communities appropriate themselves and give meaning to knowledge arriving from dominant places, developing subject-another world interrelationships ${ }^{(4)}$. The humanizing issue and quality of services began to appear with the XI National Health Conference, entitled, Effecting the UHS: access, quality and humanization in health care with social control in 2000(5). The Humanizing Care Policy and Management (Politica Nacional de Humanização $\mathrm{PNH}$ ) is a breakthrough initiative in the UHS (Unified Health System- UHS-SUS). Created in 2003, the PNH aims to qualify management and health care practices. This is a challenging task since, from the perspective of humanization, this corresponds to the production of new staff, manager and user attitudes, and new ethics in the field of work, including management and health practices, overcoming problems and challenges of daily work ${ }^{(6)}$.

Humanizing healthcare regards the welcoming, progression of understanding of welcoming, and humanistic focus to the qualification of the processes of caring for users 'demand care users processes ${ }^{(7)}$, to the need for public involvement in the development, implementation and evaluation of healthcare programs, in order to achieve consistency between user expectations and program purposes( ${ }^{(8)}$.

Currently, technological and market challenges are linked to everyday issues of the profession. From this perspective, these current tools are increasingly, rapidly renewed by produced knowledge and technological innovations, which require detailed and scientific knowledge that interferes with interpersonal relationships ${ }^{(9)}$, justifying the need to investigate the discursive production of professionals about humanizing healthcare; to think about how the policy is set up in field practice of the staff as a radical implementation and qualification. The current challenges of the PNH today still revolve around the theme of transversality and, above all, the defense of UHS as a policy, ensuring health as a social right. Therefore, the aim of this study was to describe the professionals' discursive production about humanizing health.

The results of this research could contribute to redirecting the governmental policy actions, especially in the healthcare area and especially in its humanization, sensitizing managers of these governmental actions to the investment of managers, professionals and users, with mutual accountability in the health processes and citizenship exercise, which affects citizens as co-author of the health care process $^{(10)}$. Humanizing healthcare may be provided as a structural policy of all the others in the health field, and includes citizenship ${ }^{(5)}$. From this perspective, humanization supports other policies; there is use for the existence of "policies" when they are not humanized. Being a citizen is having obligations as well as rights: healthcare is a right and without humanizing it, health becomes devoid of meaning.

\section{Method}

This was a qualitative study of descriptive approach, inspired by social representations theory, which is a research domain configured as a generator of discussion, exchange, consensus and disagreement, 
which seeks to understand how meaning is assigned to the object; how social actors interpret the social world and social relationships ${ }^{(11)}$.

The study was conducted in a federal university hospital, in Niterói, in the context of the National Policy of Humanization (PNH). The PNH was implemented in the hospital, seeking to improve relationships and strengthen humanitarian values for the users and health professionals' benefit, by actions such as creating groups and institutional projects, aiming toward welcoming and listening, open visits, artisanal works, evangelical chaplains, pastoral healthcare, recreational activities for hospitalized children, among other actions.

Selection of subjects occurred according to inclusion and exclusion criteria. The professionals with higher education who were working in the hospital were included, with time since hire exceeding one year, constituting a minimum time for adaptation and engagement, including in the humanization proposals of the institution. The exclusion criterion was: professionals from other sectors, including those who were substitutes for others' absences.

Initial contacts occurred by field visits to establish ambience and approximation to the participants; the study objectives and the importance of their participation were explained, including adequacy for the inclusion criteria. Forty professionals were addressed and 24 participated in the study. The data collection ceased when saturation of information obtained in the discussions was achieved.

The data collection technique used was an open interview, with the initiation of dialogue for deepening understanding about humanization enabled by the question: "What does humanizing health mean to you?". Interviews lasted around 30 minutes; they occurred on a day, time and place of the professionals' preference. Interviews were recorded with a digital recorder, and were conducted in the period from April to July of 2013.

Data analysis implied the capture of meaning units initially expressed by the subjects, by careful reading of each statement, separating the parts or units of meaning that, for the researchers, were fundamental structures of experience. Later, language selection of each subject was performed, capturing the unity of meaning, from which emerged the hermeneutical issues that were grounded by the social representations and interpreted in light of the proposals of authors who give consistency to a critical-reflexive questioning, according to the identified issues. In order to preserve the identity of the participants, each one received the letter $\mathrm{E}$, "examined" , with a successive numerical sequence of $1,2,3 \ldots$

As research involving human beings, all ethical and legal requirements regulated by Resolution \#466/12, of the CNS-MS were attended to. The request for participation in the study was made by presenting for signature the Terms of Free and Informed Consent (TFIC); and the research was approved by the Research Ethics Committee of the Universidade Federal Fluminense, protocol No 208.069.

\section{Results}

Among the 24 participants, 17 were nurses, three were physicians, three were social workers, and one was a physiotherapist; ages ranged from 25 to 55 years; 14 were married, living with a partner/in a stable union; 18 identified Catholicism as their religion. With regard to the professional education degree, 14 had specialization; five had earned a master's degree and one a doctorate, with the remainder with only undergraduate level education. The years since graduation were, for 12 subjects, between 1-5years, four had between 6-10 years since graduation. The monthly income was in the range of $R \$ 4,501.00$ to $R$ $\$ 5,500.00$. Thirteen professionals reported having no defined political orientation. Regarding the distribution of subjects by the number of people who lived in the same house, 17 had three or more living in the same place. Regarding the main sources of accessing information on humanization, ten people obtained this through scientific articles and manuals.

From the analysis of the statements expressed by participants, three themes were revealed around which analyses were conducted: "humanizing health as an act of accepting the other as unique", "humanizing health as a matter of right" and "humanizing health as an ethical issue". The discursive production of professionals is based on a perspective whose foundation is the humanist prospect with a socio-historical bias.

\section{Discussion}

\section{Humanizing health as an act of accepting the other as unique}

In humanizing health as an act of accepting the other as unique, we report the humanist perspective 
regarding the humanizing issue. It should be noted that, from the humanistic perspective, every human behavior exists in a context that must be interpreted not necessarily by laws and numbers, but by a qualitative understanding. Also, unverifiable assumptions are experimentally accepted. What is realized is the understanding of man as a being in the world(12). The vision of man that supports the notion of the respondents about humanizing has an epistemological foundation based on a humanistic perspective and, at the same time, it is rooted in their lived experience that they have acquired and built over years of practice in in the health care field. In this sense, professional responsibility is leveraged to the extent that the participation of society is a constitutional directive in the health care field(13). This action makes professionals signify humanizing healthcare as an act of accepting the other as unique, i.e., finding another way to deal with the singular(14). Indeed, a humanized healthcare system emphasizes improvement in communication among people involved in this process, based on respect for dignity and freedom, facilitating adequate managerial support. This system can promote favorable changes to hospital practice, which are useful for professionals and users of healthcare services(15). This was, for example, the result of a positive experience lived by nurses who worked in Benin, a country in western Africa, along the Gulf of Guinea(15).

The patient issue regarding humanization can be highlighted by placing it under the subject's point of view, focusing on this judgment of the place of experience. The place of experience has an instance that is amalgamated with the inter-subjective order. A typical statement depicting this is shared below:

Seeing the patient as a unique individual, giving comfort, warmth, understanding and meeting his needs, giving attention, all these cooperate for faster recovery (E11).

Despite all the barbarity experienced by these professionals - lack of professionals, work overload, lack of equipment - they are also in the dimension of transcendence and therefore, humans construct, deconstruct and destroy relationships with other beings like himself from a transcendental place.

Understanding the human being as a unique being with his own needs and individualities (E19).

In this coexistence, there are breaks and encounters that are the challenges of existence in which each party only makes sense in a totality that is interdependent of all parties. Man is a true hermeneutic circle of himself. He makes and breaks the existing and coexisting webs.

Thinking of the patient's individuality of being more participative in the therapeutic choices (E23).

The I-You relationship is full of intentionality to the extent that we are intentional beings, intersecting with the intentionality that unveils and reveals as one relates to another. In this sense, intentionality is an essential element of human existence, and it also moves the human being to ask about the meaning of being at every experience of which the individual is not yet aware.

Given this perspective, it is possible to think of the notion of the intersubjective encounter reflexively, since this type of encounter sets out and announces that experiences relate to each person's history. The encounter experience can only happen by promoting an openness to listening, ${ }^{(16)}$ to some extent, from a historical horizon.

The professional has this horizon because it is provided to him, especially due to his daily practice in health care services living with the other, in an affectionate coexistence in the health care field(17). The subject's experience is his sequence, his story. Thus, the place of the intersubjective encounter is in the field of the institution, which means establishment in an experience of dimension, related to which a whole series of other experiments will have sense and will form a sequence, a history, thereby allowing for understanding the nature of relationships and social interactions $^{(18)}$.

It is now about considering that the experience is this place that speaks of the existential horizon of the subject, and puts him in contact with his own vocation; integrating him into the dimension of his experience and making him regain the incarnate sense. This experience is, to some extent, a pact with another's pain, with the clients' metaphysical wound and not only with the physical aspects, therefore visible, which makes the respondent say that humanization is seeing the patient as unique.

This singularity that calls for a break from the traditional model of standardization is also appealing because it captures an insurgency that the humanizing policy can have, because such breaks provide possibilities for healing the instituted model, in order to establish a new one. It is about understanding that, in everyday life, representations play the role of methodological levers that allow for an interest in the new model, rather than in the one that was previously instituted ${ }^{(19)}$. 
Unique refers to the singularity that is so dear in a society that tends toward massification and the exaltation of the fleeting, liquidity and the objectification of the subject. Uniqueness thinks otherness, without imposing a way of being that does not take into account one's own characteristics. This requires a careful, amalgamated look with the experience of understanding others, an ability to perceive consensus and disagreement.

\section{Humanizing health as a matter of right}

In humanizing health as a matter of right, there is a tendency toward the very legalization of processes related to the issue of health. This tendency becomes stronger every day in the healthcare field. Today's new social demand is "the right to have rights"; the idea that a subject is convened by the transformation of a self-consciousness, to the extent that the subject becomes stronger than merely having the awareness of rules, and so it is postulated that the subject is also strengthened beyond the rules and the requirements of the systems in which he lives and $\operatorname{acts}^{(18)}$.

Indeed, it is the scope of practical life, of relationships that do not tire, to enroll in the subjective, intersubjective and trans-subjective world and, thus, one is in the context of social representations to the extent that they are configured as a set of concepts, propositions and explanations originating in daily life in the course of interpersonal communications ${ }^{(11)}$. The moral world intersects with and crosses these worlds, which are the world of the subject, the world of the I-You relationships, and the world of I-another. The ethical world intersects with all of those little big worlds. In American terms, humanizing is related in this sense to quality of life, care, awareness, transcendence and presence, to the extent that it relates to a theoretical and practical approach from the care perspective, thereby contributing to compliance with the well-being of society ${ }^{(20)}$.

The issue of rights, or rather the issue of right, is highlighted by a statement that brings up the concept that humanizing health: SUS proposal articulated with SUS principles, fundamentals and guidelines of SUS. It comes from the realization of existing rights (E5).

The issue of quality reflected upon from the legal point of view, the letter of the law,, the issue is a matter of human rights and that is pointed out in the respondent's statement. It is a political claim, because the history of human rights is a developing history ${ }^{(21)}$ and illustrates the synchronic and diachronic problem that spread around that proposition. Freedom brings us to the claim of rights to the extent that the subject appears from different perspectives: that of an illusion or deceptive transparency; that of an objectification of historically constituted subjectivity; that of a reflective power of resistance or surveillance; that of a freedom claiming its rights. This was seen, above, in the statements of healthcare professionals, their references to identity, responsibility, all relate to a judicial way of seeing health and humanization today; in addition, it also indicates a challenge in symbolic and political argument(16). Thus, there is a permanent increase in laws in the past five years, evidenced by the increased number of law suits in recent years(20). The professional claims that the proposition of humanizing health is: Fulfilling a constitutional right to care for and prevent, protect and produce quality health (E18).

It is therefore about thinking to what extent quality makes them co-responsible for the process, when uncoupled from other dimensions such as the issue of staff conditions, or the subject's protagonism (22). Humanizing and participative management are also expressions of quality and humanizing, and therefore need to be seen from a contextualized perspective.

It should be noted that the ethical-moral context brings with it an ethic that requires dialogue, interaction among individuals, professionals, managers, caregivers, because only then there will be an ethic built on the relationship between the subjects that will be able to position itself critically on policies, laws and on doing itself.

It should be considered that the matter of the right passes by the way I see this man standing before me, it is a matter of worldview to some extent, of existence. It must be stated that the issue of the struggle for rights seems to be an endless struggle. The professional sometimes feel deprived of it, not only the one for whom he is caring. The problem for the struggle for rights is a struggle for one's own right and the right of the patient that the professional seems to have to face.

Given this context, it can be stated that the question of right places the professional in the position to see critical life issues that call into question therapeutic projects, care strategies and even life projects that make the professional think about the 
complex object that is human care, and the dimension of existence.

Given these issues, it must be stated that the protection of rights becomes something relevant, given the recognition problems that persist in this regard, because this issue also concerns the experience of a sense of empowerment of the subject himself.

It should be said that thinking about the interface between humanizing and then health rights of subjects also reflects on the ethos that permeates the care dimension. It is necessary to clarify that this theme is added to the fact of thinking in negotiation channels, participation in decisions, labor processes in health, and that they have their voices heard within a conception of dialogue and respectful relationship.

\section{Humanizing health as an ethical issue}

In humanizing health as an ethical issue, the issue of ethics is also raised and related to the issue of humanizing, to the extent that the subjects in the study think it is articulated to ensure dignity, as one may think of the ethical dimension through dignity(23). Decent is ethical, ethical is decent, this dignity is also thought of from the place of care, offering conditions, quality and rights to health.

Therefore, the interpersonal relationship is, to some extent, the privileged locus of this production of living relationship units. This living unit is guided not only by scientific practice or anatomical and clinical experience, but also by the experience that permeates the fluidity of life, the inaccuracy of the facts, the inaccuracy of the concepts with their antinomies and dialectical elements that are part of existing, but also of coexisting. It is, therefore, about ascertaining the extent to which a response is compared to another. In this sense, international studies indicate that, with the focus on humanizing, it is believed that knowledge in this field will result in benefit to the social wellbeing, providing an understanding of the person and the common well-being(24).

The issue of freedom is an ethical issue within the labor process. It is understood that one must think that, in order to create humanization, ethical hearing of these subjects must already operate, and also realize that this is dealing with a social process.

The professional claims that humanizing health is: the ethical dignity warranty (E12).

There is, in the discourse of these professionals, a concern about ensuring ethical eminence, as if, in their experience, they could see that it is lacking in many professionals. The lack of ethics is a form of exclusion, configuring itself as a kind of injustice, and this is a type of complaint that appears in the discourse that springs from the heart of the experience of these professionals.

Considering these statements, it must be noted that this interpersonal encounter goes indeed beyond the anatomical-clinical approach, but inhabits a locus that speaks of affirmation of life even in death. This is the dimension of human subjectivity that cannot reduce man to a collection of signs and symptoms, a catalogued species.

It must be emphasized that what the professional wishes were different in regard to humanizing care comes from his practice, experience, history, temporality and does not necessarily function as one of the classifying conditions of a natural science, but rather, is based on a science that wants to understand the subject from what he turns out to be in the experience that is present through the I-You relationship. The professional understands that one needs to reconfigure the space of the encounter with the other.

In addition, it should be noted that the issue of relevance of the humanizing professional relationship with the health system user arises, despite the myth of neutrality of science, objectivity, the imposition of calculation and experimentation. It is, therefore, necessary to understand the perspectives of the settings of different qualities and dimensions of exclusion, realizing the objective dimension of social inequality, the ethical dimension of injustice, and the subjective dimension of the ethical-political suffering that crosses the inter- and trans-subjective relationships(25). Indeed, creating opportunities for the other to express is giving him status as a citizen and, more than that, it is to see him as one's equal, similar; it is also a possibility for rupturing of the hegemonic medical-centered model of technical knowledge production, in which there is no room for historical-poetic, and only for the established history, far from the instituting. In this sense, the subject also suffers politically when he experiences the elimination of popular participation in political decisions; when he watches the concentration of public power to the extent that one realizes the weakness and fragility of the state of rights law, and when he observes the control of the mass communication media, albeit indirectly and discreetly. This suffering transpires in 
the social representations of the subjects and also when exploring the issue of ethics.

The professional claims that humanizing health is: the assurance of dignity, ethics and is lacking in many professionals (E24).

This issue leads us to thinking how much the opposite of humanizing can cause suffering, inequality and a deep sense of social injustice and social suffering as exclusion(25). The whole issue can be leveraged in the social space by the weakening and rupture of social bonds of a society, as they bring consequences to daily life and in the life trajectories ${ }^{(26)}$.

The labor process is at stake in the issue of how to develop humanization. From one's set of knowledge and techniques, becoming humanized is possible. The labor process is performed by many; it is done not only by subjectivity, but subjectivities, whether individual, collective, or institutional.

Thus, it should be stated that the issue of humanizing therefore postulates the characteristic of concern with "other than me: as a structural characteristic because, to some extent, there is the issue at stake in some empathy and contingency operating these relationships; availability to others and, in particular, recognition that there are inevitable differences among humans, but they are also part of the processes and, as such, the characteristics of the humanizing process. American studies point to the fact that it is necessary to facilitate humanization, learning the meaning of existence itself, thinking of the choices, promoting quality of life, and then healing will occur in life and death $^{(27-29)}$

\section{Conclusion}

The results of this study enabled the understanding of the meaning of the professionals' discursive production about humanizing health, as they have the experience of everyday practice in health services and, especially, in a hospital in which the National Humanization Policy has been implemented.

The question of what humanizing health means for health professionals was expressed in their discursive production; they referred to it as an act of welcoming the other as unique, assigning the importance of the uniqueness issue, and also showing that this statement has a humanist foundation and at the same time is socio-historical, based in both their professional and personal experience.
The reflection also suggests humanization as a right, indicating the healthcare judicial process more frequent in our area; with permanent growth of judicial impact in the past five years, and increased number of judicial proceedings in recent years. There is an appeal for compliance with constitutional rights within the health field.

Within this perspective, humanizing health is also seen as a question of ethics to the extent that ethical dignity is considered, as well as ensuring equality, and the suffering caused when the situation of violations occurs.

Furthermore, healthcare professionals must know the National Humanizing Policy in order to provide quality care, promote meeting, welcoming and recognition of oneself, others and their profession in a political and socio-historical scenario of their country, as a citizen not only with rights but also obligations.

Education must be permanent in order to effectively put in motion the issue of humanization, as the way in which it must be developed, and education, has many nuances. It is important to consider that working conditions of health professionals have long been degraded through precarious mechanisms, ranging from not having effective professionals in sufficient quantity to the implementation of reckless expansion programs.

This study shows the discursive production of a professional group from a hospital in which the $\mathrm{PNH}$ has been implemented, which can be considered a limiting factor of the research, as it does not allow generalizing the results. However, it is proved to be relevant, as it enables healthcare professionals to rethink their actions in the humanizing health care.

\section{References}

1. Pasche FD, Passos E, Hennington EA. Cinco anos da política nacional de humanização: trajetória de uma política pública. Ciênc Saúde Coletiva. 2011;16(11):4541-8.

2. Severino AJ, Almeida CRS, Lorieri M. Perspectivas da Filosofia da Educação. São Paulo: Cortez; 2011.

3. Gouveia EC, Avila LA. Aspectos emocionais associados a disfunções gastroenterológicas. Psicol Estud. 2010;15(2):265-73.

4. Paula AS, Kodato S, Dias FX. Representações sociais da violência em professores da escola pública. Est Inter Psicol. 2013;4(2):240-57. 
5. Nora CRD, Junges JR. Política de humanização na atenção básica: revisão sistemática. Rev Saúde Pública. 2013;47(6):1186-200.

6. Pasche DF, Passos E, Hennington EA. Cinco anos da política nacional de humanização: trajetória de uma política pública. Ciênc Saúde Coletiva. [Internet] 2011 Nov [acesso 2 abr 2015];16 (11). Disponível em: $\quad$ http://www.scielo.br/scielo.php?script $=$ sci_ arttext\&pid=S1413-81232011001200027\&Ing=en\& nrm=iso. DOI: http://dx.doi.org/10.1590/S141381232011001200027.

7. Andrade MAC, Artmann E, Trindade ZA. Humanização da saúde em um serviço de emergência de um hospital público: comparação sobre representações sociais dos profissionais antes e após a capacitação. Ciênc Saúde Coletiva. 2011;16(Suppl I):1115-24.

8. Augusto VG, Aquino CF, Machado NC, Cardoso VA, Ribeiro S. Promoção de saúde em unidades básicas: análise das representações sociais dos usuários sobre a atuação da fisioterapia. Ciênc Saúde Coletiva. 2011;16(suppl I):957-63.

9. Menezes SRT, Priel MR, Pereira LL. Autonomia e vulnerabilidade do enfermeiro na prática da Sistematização da Assistência de Enfermagem. Rev Esc Enferm USP. 2011;45(4):953-8.

10. Ferreira VF, Rocha GOR, Lopes MMB, Santos MS, Miranda SA. Educação em saúde e cidadania: revisão integrativa. Trab Educ Saúde. 2014;12(2):363-78.

11. Silva AMTB, Constantino GD, Premaor VB. A contribuição da teoria das representações sociais para análise de um fórum de discussão virtual. Temas Psicol. 2011;19(1):233-42.

12. Freire JC. Humanismo e Fenomenologia: na psicologia, na psicopatologia e na psicoterapia. Paidéia. 2010;20(45):133-4.

13. Silva RCC, Pedroso MC, Zucchi P. Ouvidorias públicas de saúde: estudo de caso em ouvidoria municipal de saúde. Rev Saúde Pública. 2014;48(1):134-41.

14. Barbosa LB, Dimenstein M, Leite JF. Mulheres, violência e atenção em saúde mental: questões para (re) pensar o acolhimento no cotidiano dos serviços. Av Psicol Latinoam. 2014;32(2):309-20.

15. Fujita N, Perrin XR, Vodounon JA, Gozo MK, Matsumoto $Y$, Uchida $S$, et al Humanised care and a change in practice in a hospital in Benin. Midwifery. 2012 Aug;28(4):481-8.

16. Paula CC, Padoin SMM, Terra MG, Souza IEO, Cabral IE. Modos de condução da entrevista em pesquisa fenomenológica: relato de experiência. Rev Bras Enferm. 2014;67(3):468-72.
17. Nascimento MC, Barros NF, Nogueira MI, Luz MT. A categoria racionalidade médica e uma nova epistemologia em saúde. Ciênc Saúde Coletiva. 2013;18(12):3595-604.

18. Jodelet D. O movimento de retorno ao sujeito e a abordagem das representações sociais. Soc Estado. 2009;24(3):679-712.

19. Carneiro MS. Práticas, discursos e arenas: notas sobre a socioantropologia do desenvolvimento. Sociol Antropol. 2012;2(4):129-58.

20. Dobratz MC. A model of consensus formation for reconciling nursing's disciplinary matrix. Nurs Philos. 2010 Jan;11(1):53-66.

21. Eyng AM. Direitos humanos e violência nas escolas: desafios do trabalho em rede. Rev Port de Educação. 2013;26(2):245-66.

22. Diniz DMTRC, Penalva J. A judicialização da saúde no Distrito Federal, Brasil. Ciênc Saúde Coletiva. 2014;19(2):591-8.

23. Tocci ASS, Costa ECNF. A gestão em saúde após a Política Nacional de Humanização no Sistema Único de Saúde - SUS. Rev UNINGÁ. 2014;(40):197-206.

24. Widang I, Fridlund B, Martenson, J. Women patients' perceptions of integrity within health care: A phenomenographic study. J Adv Nurs. 2008;61(5):540-8.

25. McCurry MK, Revell SM, Roy SC. Knowledge for the good of the individual and society: linking philosophy, disciplinary goals, theory, and practice.

Nurs Philos. 2010 Jan;11(1):42-52.

26. Reis NHN. Ética na contemporaneidade: elementos para uma análise. Enfoques. 2011;23(1):57-73.

27. Sawaia B, organizador. As artimanhas da exclusão. 11ed. Petrópolis: Vozes; 2011.

28. Morse JM. Why humanized health care? Plenary address. Saiyud Niymviphat Lecture at the First Asian International Conference on Humanized Health Care, 2007 Dec 3-5; Khon Kaen, Thailand. p. 74-81.

29. Arman M, Rannheim A, Rehnsfeldt A, Wode K. Anthroposophic healthcare*different and homelike. Scand J Caring Sci. 2008;22:357-66.

30. Willis DG, Grace PJ. Roy C. A central unifying focus for the discipline: facilitating humanization, meaning, choice, quality of life, and healing in living and dying. ANS Adv Nurs Sci. 2008 Jan/ Mar;31(1):E28-40.

31. Drummond JP. Bioética, dor e sofrimento. Cienc Cult. $2011 ; 63(2): 32-7$.

32. Alves H, Escorel S. Processos de exclusão social e iniquidades em saúde: um estudo de caso a partir 
do Programa Bolsa Família, Brasil. Rev Panam Salud Publica. 2013; 34(6):429-36.

Received: Oct. $25^{\text {th }} 2014$

Accepted: Apr. 22 2015 